NASA/TM-2007-214811

Near Field Radiation Characteristics of Implantable Square Spiral Chip Inductor Antennas for Bio-Sensors

James A. Nessel, Rainee N. Simons, and Felix A. Miranda

Glenn Research Center, Cleveland, Ohio 


\section{NASA STI Program . . . in Profile}

Since its founding, NASA has been dedicated to the advancement of aeronautics and space science. The NASA Scientific and Technical Information (STI) program plays a key part in helping NASA maintain this important role.

The NASA STI Program operates under the auspices of the Agency Chief Information Officer. It collects, organizes, provides for archiving, and disseminates NASA's STI. The NASA STI program provides access to the NASA Aeronautics and Space Database and its public interface, the NASA Technical Reports Server, thus providing one of the largest collections of aeronautical and space science STI in the world. Results are published in both non-NASA channels and by NASA in the NASA STI Report Series, which includes the following report types:

- TECHNICAL PUBLICATION. Reports of completed research or a major significant phase of research that present the results of NASA programs and include extensive data or theoretical analysis. Includes compilations of significant scientific and technical data and information deemed to be of continuing reference value. NASA counterpart of peer-reviewed formal professional papers but has less stringent limitations on manuscript length and extent of graphic presentations.

- TECHNICAL MEMORANDUM. Scientific and technical findings that are preliminary or of specialized interest, e.g., quick release reports, working papers, and bibliographies that contain minimal annotation. Does not contain extensive analysis.

- CONTRACTOR REPORT. Scientific and technical findings by NASA-sponsored contractors and grantees.
- CONFERENCE PUBLICATION. Collected papers from scientific and technical conferences, symposia, seminars, or other meetings sponsored or cosponsored by NASA.

- SPECIAL PUBLICATION. Scientific, technical, or historical information from NASA programs, projects, and missions, often concerned with subjects having substantial public interest.

- TECHNICAL TRANSLATION. Englishlanguage translations of foreign scientific and technical material pertinent to NASA's mission.

Specialized services also include creating custom thesauri, building customized databases, organizing and publishing research results.

For more information about the NASA STI program, see the following:

- Access the NASA STI program home page at http://www.sti.nasa.gov

- E-mail your question via the Internet to help@sti.nasa.gov

- Fax your question to the NASA STI Help Desk at 301-621-0134

- Telephone the NASA STI Help Desk at 301-621-0390

- Write to: NASA Center for AeroSpace Information (CASI) 7115 Standard Drive Hanover, MD 21076-1320 
NASA/TM-2007-214811

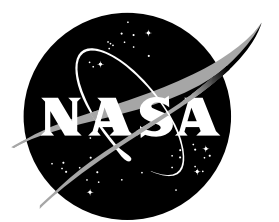

\section{Near Field Radiation Characteristics of Implantable Square Spiral Chip Inductor Antennas for Bio-Sensors}

James A. Nessel, Rainee N. Simons, and Felix A. Miranda

Glenn Research Center, Cleveland, Ohio

Prepared for the

2007 International Symposium and National Radio Science Meeting sponsored by the IEEE Antennas and Propagation Society and URSI Honolulu, Hawaii, June 9-15, 2007

National Aeronautics and

Space Administration

Glenn Research Center

Cleveland, Ohio 44135 
This report is a preprint of a paper intended for presentation at a conference.

Because changes may be made before formal publication, this preprint is made available with the understanding that it will not be cited or reproduced without the permission of the author.

Level of Review: This material has been technically reviewed by technical management.

Available from

NASA Center for Aerospace Information 7115 Standard Drive

Hanover, MD 21076-1320
National Technical Information Service 5285 Port Royal Road Springfield, VA 22161 


\title{
Near Field Radiation Characteristics of Implantable Square Spiral Chip Inductor Antennas for Bio-Sensors
}

\author{
James A. Nessel, Rainee N. Simons, and Felix A. Miranda \\ National Aeronautics and Space Administration \\ Glenn Research Center \\ Cleveland, Ohio 44135
}

\section{Introduction}

NASA's Exploration Vision initiative calls for the completion of the International Space Station (ISS) by 2010 and the return of human beings to the Moon by 2018, with a subsequent exploration initiative to Mars called for 2030 and beyond [1]. The challenges and risk for humans involved in the different stages of the Exploration Vision have been summarized in NASA's Bioastronautic Roadmap [2]. For example, the prolonged stay of astronauts either in the ISS, the Moon or Mars, will induce biological changes that must be carefully monitored to guarantee the astronauts' well being and safety. Therefore, development of crew physiological monitoring devices for autonomous medical care is an area of high interest for NASA. Although novel health monitoring concepts have been developed to ensure astronaut safety during space flight related activities, these are generally electrode and wireline-based, and hence limited to external use [3]. On the other hand, development of space-qualified implantable sensors, that could be used to monitor recovery from injuries or chronic but treatable conditions of crew members during extended presence in space (e.g., one-year ISS mission; 30 month journey to Mars, etc.) are yet to be fully developed. Consequently, development of wireless, versatile monitoring techniques for embedded bio-sensors are highly desirable. In previous work, the authors have studied thoroughly the fundamental components (i.e., the embedded as well as the hand-held subsystems) of a wireless telemetry system for BioSensors [4-10]. In this work, we present the experimental characterization of implantable square spiral chip inductor antennas (SSCIA) in free space. Our results indicate that the measured near field relative signal strength of the SSCIA agrees with simulated results and confirm that in the near field region the radiation field is fairly uniform in all directions [8]. The results show the applicability of SSCIA's for the intended application.

\section{Implantable Square Spiral Chip Inductor Antenna}

A schematic and photomicrographs of the circuit and ground plane sides of the fabricated miniature printed SSCIA on high resistivity silicon wafer $\left(\rho>2500 \Omega\right.$-cm \& $\left.\varepsilon_{\mathrm{r}}=11.7\right)$ are shown in Figs. 1(a)-(c), respectively. Several designs of these antennas were step-andrepeated across the wafer and fabricated using photolithography techniques [4-6]. Results of the near field characterization for four such antennas are reported in this paper.

\section{Measurement Setup}

GRC's Planar Near-Field Probe Station Scanner (PNFPSS) was utilized to measure the near field relative signal strength emitted by the antenna under test (AUT), i.e., the SSCIA. A block diagram and a photo of the experimental set-up are shown in Figs. 2(a) and (b), respectively. Since the antennas were not designed with a $50 \Omega$ impedance match at their operating frequency of $330 \mathrm{MHz}$, two sets of amplifiers were implemented to ensure a measurable signal was obtained. Power amplification of the $0 \mathrm{dBm}$ power 


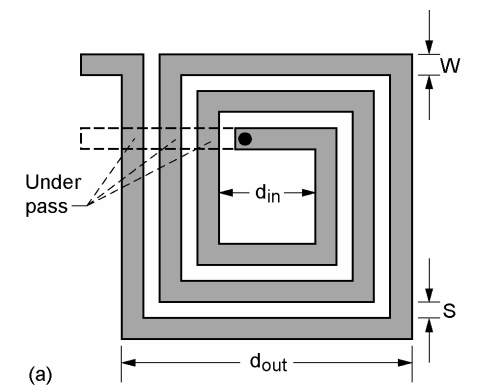

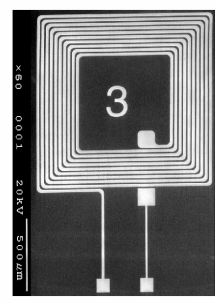

(b)

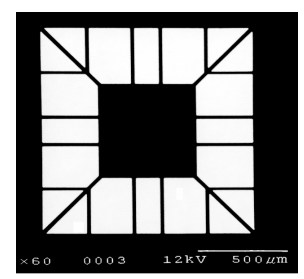

(c)

Figure $1-$ (a) Schematic of the SSCIA, $d_{\text {in }}=0.5 \mathrm{~mm}, \mathrm{~d}_{\text {out }}=1.0 \mathrm{~mm}$. Photomicrograph of (b) SSCIA and (c) Serrated ground plane (1 $\mathrm{mm} \times 1 \mathrm{~mm})$.

from an HP 8510C Vector Network Analyzer (VNA) was provided via a Medium Power Amplifier (MPA). The MPA provided $20 \mathrm{~dB}$ power amplification, and hence nearly 20 $\mathrm{dBm}$ of power was input to the AUT, since RF cable losses were negligible. At a $5 \mathrm{~cm}$ distance above the antenna, a dipole probe was used to scan a planar field from boresight to a $45^{\circ}$ semi-cone angle to measure the relative radiated power coupled from the AUT to the probe. On the receive end, a Low Noise Amplifier (LNA) supplied another $15 \mathrm{~dB}$ of gain to the signal. An $\mathrm{S}_{21}$ measurement conducted over a $5 \mathrm{~cm}$ x $10 \mathrm{~cm}$ scan plane thus provided the spatial dependence of the relative signal strength from the AUT.

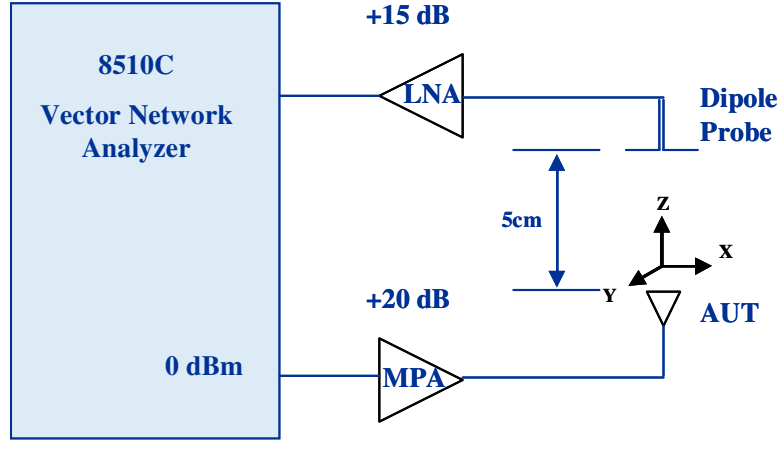

(a)

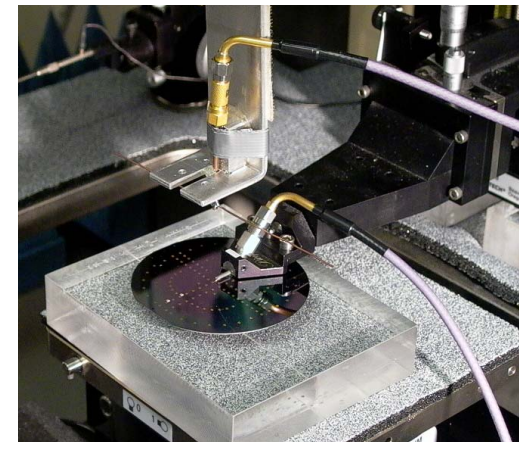

(b)

Figure 2 - (a) Block diagram of the setup implemented for the measurement of the SSCIA. (b) Photo of the on-wafer SSCIA mounted in the PNFPSS.

\section{Results and Discussions}

Multiple wafers with and without a ground plane were characterized in the near field. Table I summarizes the geometrical parameters of four of these antennas investigated in this paper. Antenna A-VI was fabricated on a wafer with a serrated ground plane and was measured to investigate the performance of the SSCIA as fabricated for the intended application. Antennas A1, A3, and A6 were fabricated on a second wafer, with no ground plane, to study the effects of strip/gap width and number of turns on the near-field radiation properties of the SSCIA. A-VI is identical in electrical design to antenna A6, except for the presence of a serrated ground plane. Previous results [5] have indicated that the serrated ground plane suppressed the eddy currents and hence improved the loss characteristics of the antenna. Thus, this configuration was the only antenna with ground plane measured in this paper. Fig. 3 compares the relative signal strength of each antenna as coupled to the probe in the near field. 
Table I: Characteristics of SSCIA Antennas

\begin{tabular}{lcccc}
\hline Antenna & $\begin{array}{c}\text { Inner Strip }(W) / \\
\operatorname{Gap}(S) \text { Width }(\mu \mathrm{m})\end{array}$ & $\begin{array}{c}\text { Outer Strip }(W) / \\
\operatorname{Gap}(S) \text { Width }(\mu \mathrm{m})\end{array}$ & $\begin{array}{c}\text { No. of } \\
\text { Turns }\end{array}$ & $\begin{array}{c}\text { Bottom side of } \\
\text { wafer }\end{array}$ \\
\hline A-VI & $15 / 10$ & $15 / 15$ & 10 & Serrated ground \\
A1 & $10 / 10$ & $10 / 10$ & 13 & No ground \\
A3 & $15 / 10$ & $15 / 10$ & 10 & No ground \\
A6 & $15 / 10$ & $15 / 15$ & 10 & No ground \\
\hline
\end{tabular}

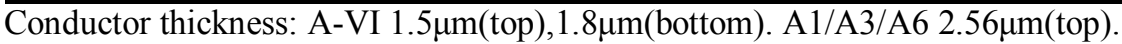

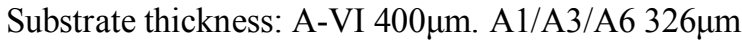

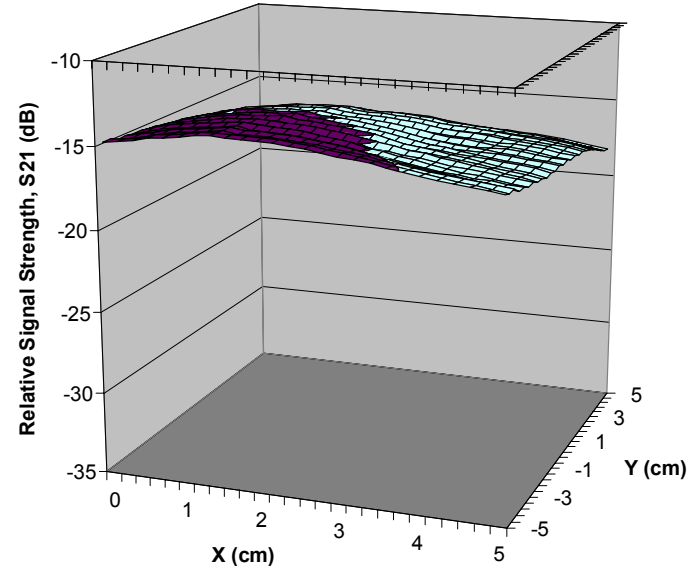

(a)

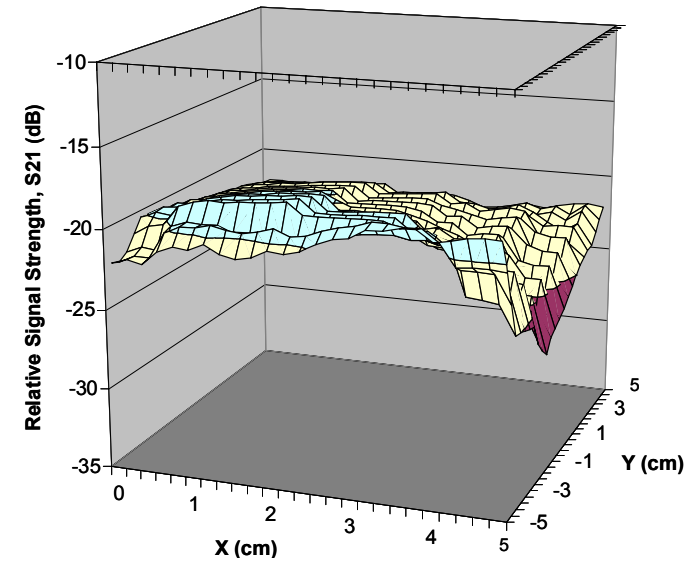

(c)

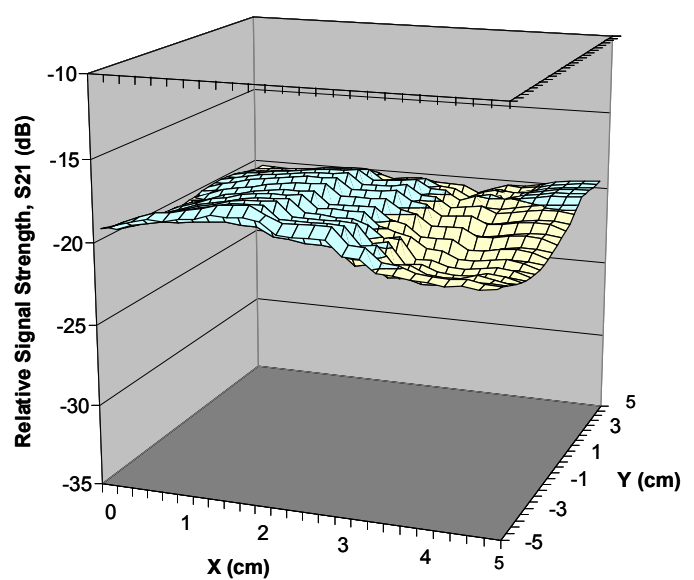

(b)

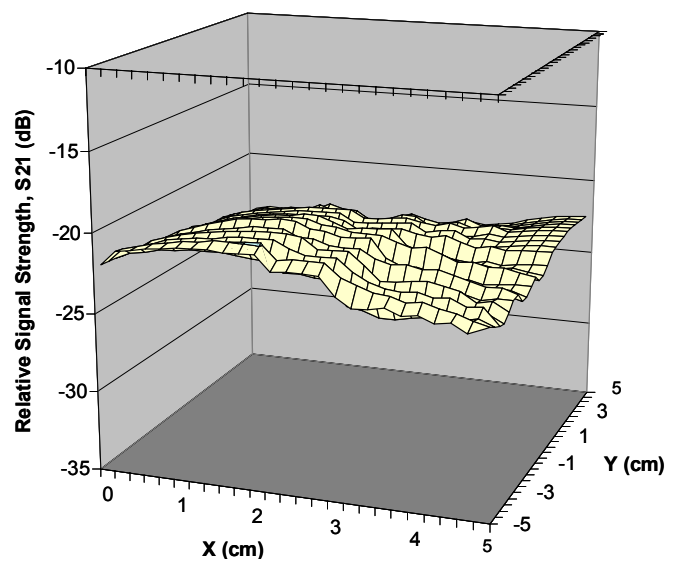

(d)

Figure 3 - Measured relative signal strength, $S_{21}(\mathrm{~dB})$, over a $5 \mathrm{~cm} \times 10 \mathrm{~cm}$ planar field at a height of $5 \mathrm{~cm}$ and frequency of $330 \mathrm{MHz}$. The origin of the coordinate system coincides with the geometric center of the SSCIA (a) A-VI, (b) A1, (c) A3, and (d) A6.

The following observations can be made based on the experimental measurements of the different types of SSCIA. Fig. 3(a) shows that the SSCIA with serrated ground plane produces a broad radiation pattern with a relative signal strength detectable at distances typical of hand held devices for self-diagnosis. In addition, the broad radiation pattern would reduce the requirement of placing the hand-held device at a specific location or orientation while reading the data from the embedded Bio-Sensor. Although a direct comparison of the absolute signal strength radiated by antennas A-VI and A6 is not 
possible, due to the fabrication differences, the effect of other parameters on the performance of the SSCIA's could be observed from the other antennas studied in this paper. Antennas A3 and A6 possess the same number of turns with slightly different gap widths (10 vs. $15 \mu \mathrm{m}$ in the outer loops of the antenna). Comparing Fig. 3(c) with Fig. 3(d) indicates that a wider outer gap width tends to decrease relative signal strength. Also, increasing the number of turns from 10 (A3/Fig. 3(c)) to 13 (A1/Fig. 3(b)) increased relative signal strength by approximately $1-2 \mathrm{~dB}$.

\section{Conclusions}

The near field radiation characteristics of implantable Square Spiral Chip Inductor Antennas (SSCIA's) for Bio-Sensors have been measured. Our results indicate that the measured near field relative signal strength of these antennas agrees with simulated results and confirm that in the near field region the radiation field is fairly uniform in all directions. The effects of parameters such as ground-plane, number of turns and microstrip-gap width on the performance of the SSCIA were presented. Furthermore, the SSCIA antenna with a serrated ground plane produces a broad radiation pattern, with a relative signal strength detectable at distances within the range of operation of handheld devices for self-diagnosis.

\section{References}

[1] 2006 NASA Strategic Plan (NP-2006-02-423-HQ).

[2] BioAstronautics Roadmap: A Risk Reduction Strategy for Human Space Exploration, NASA/SP-2004-6113 (February 2005).

[3] "LifeGuard: Wireless Physiological Monitor" (www.nasa.gov/centers/ames/reasearch/technology-onepagers/life-guard.html).

[4] R.N. Simons, D.G. Hall, and F.A. Miranda, "RF Telemetry System for an Implantable Bio-MEMS Sensor," 2004 IEEE MTT-S, Int. Microwave Symp. Dig., Vol. 3, pp. 1433-1436, June 6-11, 2004. Also, NASA/TM-2004-212899.

[5] R.N. Simons, D.G. Hall, and F.A. Miranda, "Spiral Chip Implantable Radiator and Printed Loop External Receptor for RF Telemetry in Bio-Sensor Systems," Proc. 2004 IEEE Radio and Wireless Conference, Sep. 2004, p. 203-206; Also NASA/TM-2004-213217.

[6] R.N. Simons, D.G. Hall, and F.A. Miranda, "Printed Multi-Turn Loop Antenna for RF Bio-Telemetry," 2004 IEEE Ant\&Prop. Inter. Symp., June 2004, p. 1339-1342.

[7] F.A. Miranda, R.N. Simons, and D.G. Hall, "Validation of Radio Frequency Telemetry Concept in the Presence of Biological Tissue-Like Stratified Media," 2004 IEEE Ant\&Prop. Inter. Symp., June 2004, p. 1335-1338; Also NASA/TM2004-213127.

[8] R.N. Simons and F.A. Miranda, "Radiation Characteristics of Miniature Silicon Square Spiral Chip Antenna for Implantable Bio-MEMS Sensors," 2005 IEEE Ant\&Prop. Inter. Symp., July 2005, p. 836-839; Also NASA/TM-2005-213563.

[9] R.N. Simons and F.A. Miranda, "Modeling of Near Field Coupling Between an External Loop and an Implantable Spiral Chip Antennas in Biosensor Systems," 2006 IEEE Ant\&Prop. Inter. Symp., July 2006, p. 1099-1102; Also NASA/TM2006-214337.

[10] R.N. Simons, F.A. Miranda, J.D. Wilson, and R.E. Simons, "Wearable Wireless Telemetry System for Implantable Bio-MEMS Sensors," $28^{\text {th }}$ Annual International Conference of IEEE Engineering in Medicine and Biology Society (IEEE EMBS), August 2006, p. 6245-6248; Also NASA/TM-2206-214422 (October 2006). 


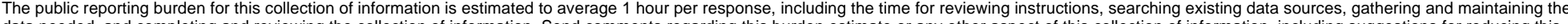

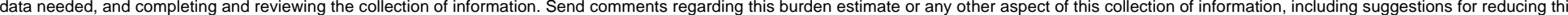

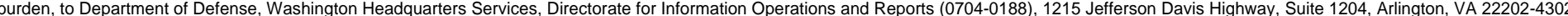

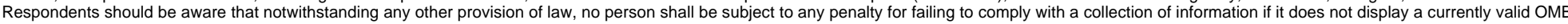
control number.

PLEASE DO NOT RETURN YOUR FORM TO THE ABOVE ADDRESS.

\section{REPORT DATE $(D D-M M-Y Y Y Y)$ \\ 2. REPORT TYPE \\ 3. DATES COVERED (From - To)}

11-07-2007

Technical Memorandum

\section{TITLE AND SUBTITLE}

Near Field Radiation Characteristics of Implantable Square Spiral Chip Inductor Antennas for

Bio-Sensors

\section{AUTHOR(S)}

Nessel, James, A.; Simons, Rainee, N.; Miranda, Felix, A.

\section{5a. CONTRACT NUMBER}

5b. GRANT NUMBER

5c. PROGRAM ELEMENT NUMBER

5d. PROJECT NUMBER

5e. TASK NUMBER

5f. WORK UNIT NUMBER

WBS 685676.01.03.01

8. PERFORMING ORGANIZATION REPORT NUMBER

E-15966

National Aeronautics and Space Administration

John H. Glenn Research Center at Lewis Field

Cleveland, Ohio 44135-3191

9. SPONSORING/MONITORING AGENCY NAME(S) AND ADDRESS(ES)

National Aeronautics and Space Administration

Washington, DC 20546-0001

\section{DISTRIBUTIONIAVAILABILITY STATEMENT}

Unclassified-Unlimited

Subject Category: 32

Available electronically at http://gltrs.grc.nasa.gov

This publication is available from the NASA Center for AeroSpace Information, 301-621-0390

\section{SUPPLEMENTARY NOTES}

\section{ABSTRACT}

The near field radiation characteristics of implantable Square Spiral Chip Inductor Antennas (SSCIA) for Bio-Sensors have been measured. Our results indicate that the measured near field relative signal strength of these antennas agrees with simulated results and confirm that in the near field region the radiation field is fairly uniform in all directions. The effects of parameters such as ground-plane, number of turns and microstrip-gap width on the performance of the SSCIA are presented. Furthermore, the SSCIA antenna with serrated ground plane produce a broad radiation pattern, with a relative signal strength detectable at distances within the range of operation of hand-held devices for self-diagnosis.

\section{SUBJECT TERMS}

Spiral antennas; Miniature antennas; Biomedical applications; Near field radiation patterns

\section{SECURITY CLASSIFICATION OF:}

\section{a. REPORT}

$\mathrm{U}$

\section{$\mathrm{U}$}

17. LIMITATION OF ABSTRACT

18. NUMBER
OF
PAGES
10

\section{TPONSORING/MONITORS ACRONYM(S) \\ NASA}

11. SPONSORING/MONITORING REPORT NUMBER

NASA/TM-2007-214811

C. THIS
PAGE
$\mathrm{U}$

19a. NAME OF RESPONSIBLE PERSON James A. Nessel 19b. TELEPHONE NUMBER (include area code) 216-433-2546 

